\title{
OXYGEN DIFFUSION MECHANISMS IN TWO SERIES OF OXIDE ION CONDUCTORS: BIMEVOX AND BROWNMILLERITE MATERIALS
}

\author{
Rolle, Aurelie ${ }^{1}$; Roussel, Pascal ${ }^{1}$; Kongmark, Chanapa ${ }^{1}$; Pirovano, Caroline ${ }^{1}$; Vannier, Rose- \\ Noëlle ${ }^{1}$ \\ 1. UCCS : Unité de Catalyse et de Chimie du Solide, UMR CNRS 8181 \\ Ecole Nationale Supérieure de Chimie de Lille, Université des Sciences et Technologies de Lille, \\ Bâtiment C7, BP 90108, \\ 59652 Villeneuve d'Ascq Cedex, France.
}

\section{ABSTRACT}

The BIMEVOX and Brownmillerite materials have as common point a layered structure with intrinsic oxygen vacancies. These defects confer to these compounds high oxide ion conduction.

The BIMEVOX were evidenced by members of our group at the end of the eighties. They derive from the parent compound $\mathrm{Bi}_{4} \mathrm{~V}_{2} \mathrm{O}_{11}$ and were obtained by partial substitution for vanadium with a metal. They are still considered as the best oxide ion conductors at moderate temperature, $400-700^{\circ} \mathrm{C}$, but suffer of a lack of stability under reducing conditions.

During the same period, Goodenough evidenced high oxide conduction in the Brownmillerite $\mathrm{Ba}_{2} \mathrm{In}_{2} \mathrm{O}_{5}$, above $925^{\circ} \mathrm{C}$. In order to stabilize this property at lower temperature, numerous partial substitutions were performed on either the $\mathrm{Ba}$ or the In site. Our group considered the partial substitution for indium with cations such as Sn, V, Ta, Nb, Mo and W. Solid solutions were obtained for all the dopants. By combining various techniques, among which atomistic simulation, X-ray diffraction, neutron diffraction, impedance spectroscopy, ${ }^{18} \mathrm{O} /{ }^{16} \mathrm{O}$ isotope exchange, the transport of oxygen in these two families of materials was characterized from the atomic scale to the macroscopic scale.

\section{INTRODUCTION}

Although discovered since more than one century, the stabilized zirconia remains the more developed material for applications such as Solid Oxide Fuel Cells, sensors or membranes for gas separation. Its properties are due to its cubic structure, similar to that of the fluorite, with extrinsic vacancies.

With a similar structure, the bismuth oxide, $\mathrm{Bi}_{2} \mathrm{O}_{3}$, in its high temperature form, $\delta$, can be considered as the best oxide conductor with a conductivity of $1{\mathrm{~S} . \mathrm{cm}^{-1}}^{-1}$ at $800^{\circ} \mathrm{C}$. Despite excellent properties this oxide could not be developed. The $\delta$ form is unfortunately stable only on a very narrow domain in temperature, limited by the melting of the oxide to $830^{\circ} \mathrm{C}$ and by a phase transition at $730^{\circ} \mathrm{C}$ which is accompanied with strong mechanical strains which make impossible the sintering of this oxide. Under the impulse of Jean-Claude Boivin, the team of Solid State Chemistry at the UCCS devoted a big part of its research to the stabilization of the excellent properties of this oxide at lower temperature ${ }^{1}$. The BIMEVOX family was evidenced at the end of the eighties ${ }^{2}$. It derived from the parent compound $\mathrm{Bi}_{4} \mathrm{~V}_{2} \mathrm{O}_{11}$ and is obtained by partial substitution for vanadium with a metal to allow the stabilization, at room temperature, of the high temperature form, $\gamma$, which exhibits high oxide ion conduction above $570^{\circ} \mathrm{C}^{3}$. From the structural point of view, most of oxide ion conducting ceramics (except apatites) derive from the fluorite or from the perovskite and the average structure of the BIMEVOX can be described as 
an intergrowth of these two structural types. It is built upon $\mathrm{Bi}_{2} \mathrm{O}_{2}$ layers of the fluorite type spaced with $\mathrm{V}(\mathrm{Me}) \mathrm{O}_{3.5} \square_{0.5}$ slabs of the perovskite type which exhibit intrinsic oxygen vacancies. It is the presence of these vacancies and the stereoactivity of the bismuth lone pair which explains the excellent properties of these materials.
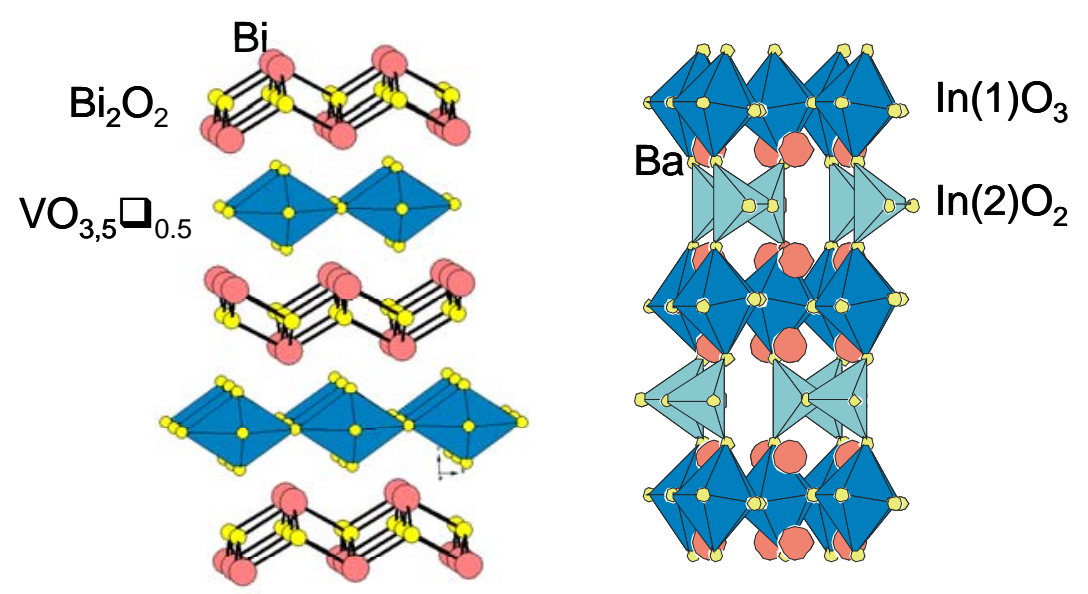

Figure 1. a) $\mathrm{Bi}_{4} \mathrm{~V}_{2} \mathrm{O}_{11}$ and b) $\mathrm{Ba}_{2} \mathrm{In}_{2} \mathrm{O}_{5}$ structures

In 1990, Goodenough evidenced excellent properties of conduction for the Brownmillerite $\mathrm{Ba}_{2} \mathrm{In}_{2} \mathrm{O}_{5}$, above $925^{\circ} \mathrm{C}^{4,5}$. Like BIMEVOX, $\mathrm{Ba}_{2} \mathrm{In}_{2} \mathrm{O}_{5}$ exhibits, at room temperature, a two-dimensional structure. This structure derives from the perovskite and can be described like the intergrowth of layers of octahedrons, [ $\left.\mathrm{InO}_{3}\right]$, and tetrahedrons, $\left[\mathrm{InO}_{2}\right]$, the barium atoms being located in the sites between these layers. When the temperature increases, the oxygen vacancies located in the tetrahedral layers at room temperature, disorder and the material becomes an oxide ion conductor. Many studies were also carried out to stabilize the high temperatures forms of the Brownmillerite at lower temperature ${ }^{5-16}$. Our team considered the partial substitution for indium with elements of valence higher than three in order to introduce additional oxide ions in the structure ${ }^{17}$. Tin, vanadium, molybdenum and tungsten were studied. Solid solutions were obtained in all cases and led to the stabilization at lower temperature of the required forms. By combining various techniques, among which, atomistic simulation, X-ray diffraction, neutron diffraction, impedance spectroscopy, ${ }^{18} \mathrm{O} /{ }^{16} \mathrm{O}$ isotope exchange, the oxygen transport in these two families of materials was characterized from the atomic scale to the macroscopic scale.

\section{OXYGEN TRANSPORT AT THE ATOMIC SCALE}

Simulation techniques are based upon energy minimization procedures. Thanks to the description of interatomic potentials, energetics of extrinsic defects and of various mechanisms or pathways for oxygen migration can be explored. The software develops by Gale ${ }^{18}$ was used for these calculations. The structure of $\mathrm{Bi}_{4} \mathrm{~V}_{2} \mathrm{O}_{11}$, with intrinsic oxygen vacancies, being too complicated to simulate and having no model of potential for vanadium, calculations were carried out on a compound of structure close to that of the BIMEVOX: $\mathrm{Bi}_{2} \mathrm{WO}_{6}{ }^{19} \cdot \mathrm{Bi}_{2} \mathrm{WO}_{6}$ exhibits the same structure as BIMEVOX but without oxygen vacancy. Its electrical properties, initially very weak, were strongly improved when tungsten was partially substituted by tantalum 
or niobium ${ }^{20}$. They were measured by impedance spectroscopy and are compared to those of $\mathrm{Bi}_{4} \mathrm{~V}_{2} \mathrm{O}_{11}$ and $\mathrm{Ba}_{2} \mathrm{In}_{2} \mathrm{O}_{5}$ in the following figure.

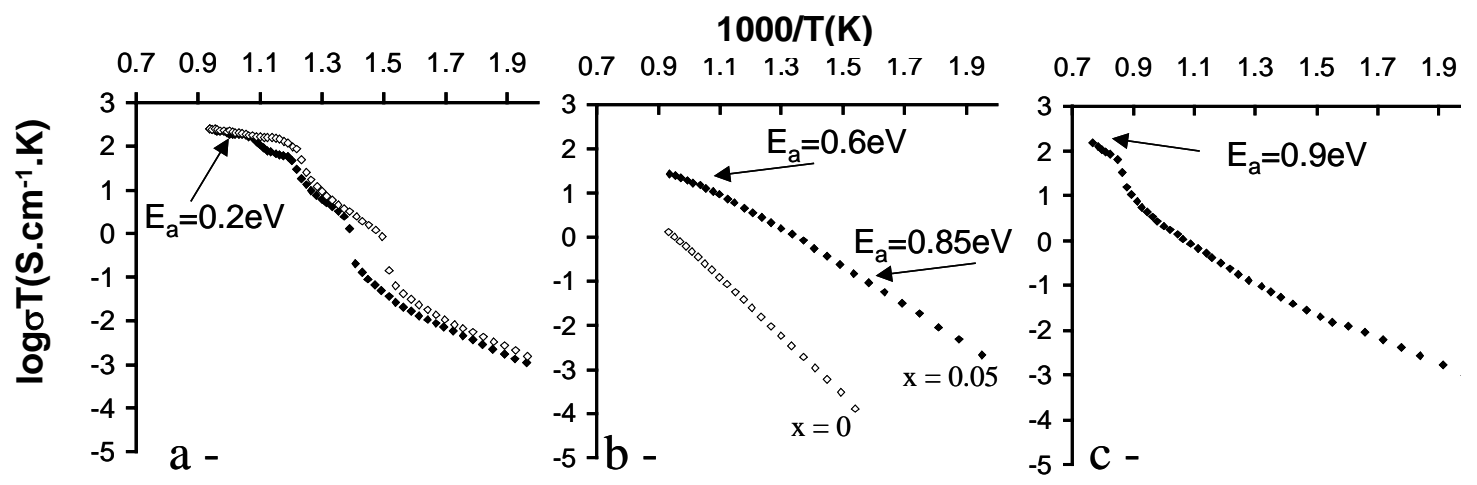

Figure 2. Arrhenius plot of the conductivity of

a) $\mathrm{Bi}_{4} \mathrm{~V}_{2} \mathrm{O}_{11}$ b) $\mathrm{Bi}_{2} \mathrm{WO}_{6}$ and $\mathrm{Bi}_{2} \mathrm{~W}_{0.95} \mathrm{Ta}_{0.05} \mathrm{O}_{5.975}$ and c) $\mathrm{Ba}_{2} \mathrm{In}_{2} \mathrm{O}_{5}$

An activation energy of $0.9 \mathrm{eV}$ was observed for the high temperature domain of $\mathrm{Ba}_{2} \mathrm{In}_{2} \mathrm{O}_{5}$, it was only $0.2 \mathrm{eV}$ for the $\gamma-\mathrm{Bi}_{4} \mathrm{~V}_{2} \mathrm{O}_{11}$ form. For bismuth tungsten oxide partially substituted with $5 \%$ of tantalum, two domains were observed on the Arrhenius plot, with an energy of activation of $0.6 \mathrm{eV}$ at high temperature and $0.85 \mathrm{eV}$ below $500^{\circ} \mathrm{C}$. To understand the oxygen diffusion mechanisms at the atomic scale, several types of defects were considered in the structures of $\mathrm{Ba}_{2} \mathrm{In}_{2} \mathrm{O}_{5}$ and $\mathrm{Bi}_{2} \mathrm{WO}_{6}$. In case of the Brownmillerite, the most favorable defect was the formation of an oxygen vacancy in the octahedral layers associated to an interstitial oxide in the tetrahedral layers. A defect energy of $0.91 \mathrm{eV}$ was derived, it was in good agreement with a previous study by Fischer $^{21}$ and also with the experimental value of $0.9 \mathrm{eV}$. An increase of the Frenkel defect concentration would explain the sudden increase in conductivity observed for this compound for temperatures higher than $925^{\circ} \mathrm{C}$. This leads to a complete disorder of the oxygen vacancies above $1040^{\circ} \mathrm{C}$, temperature at which the structure transforms to the cubic perovskite.

The structure of $\mathrm{Bi}_{2} \mathrm{WO}_{6}$ was described in the $\mathrm{Pca} 2_{1}$ space group ${ }^{22}$ with the oxide ions located on six different crystallographic sites.
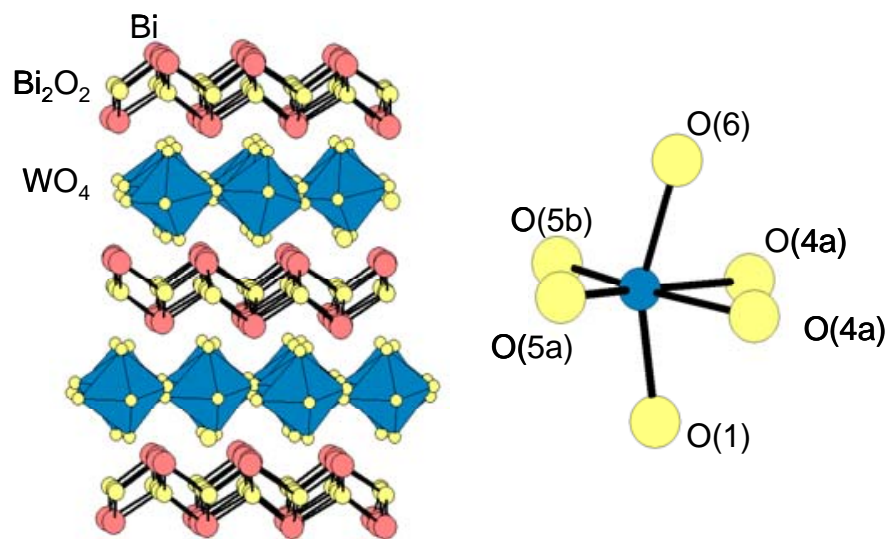

Figure $3 . \mathrm{Bi}_{2} \mathrm{WO}_{6}$ structure 
To derive preferential oxygen diffusion pathways, an intermediate state, with an oxide ion placed between two oxygen vacancies, was considered. The resulting migration energies of a range of oxygen jumps are reported in table 1.

Table 1. Energies of oxygen migration in $\mathrm{Bi}_{2} \mathrm{WO}_{6}$

\begin{tabular}{|llll|}
\hline migration pathways & $\mathrm{E}_{\mathrm{mig}} / \mathrm{eV}$ & migration pathways & $\mathrm{E}_{\mathrm{mig}} / \mathrm{eV}$ \\
& & & \\
$\mathrm{WO}_{6}$ (apical-equatorial) & & $\mathrm{WO}_{6}$ (equatorial-equatorial) & \\
$\mathrm{O}(1)-\mathrm{O}(4 \mathrm{a})$ & 0,97 & $\mathrm{O}(4 \mathrm{a})-\mathrm{O}(4 \mathrm{~b})$ & 1,67 \\
$\mathrm{O}(1)-\mathrm{O}(4 \mathrm{~b})$ & 0,45 & $\mathrm{O}(4 \mathrm{a})-\mathrm{O}(5 \mathrm{~b})$ & 1,61 \\
$\mathrm{O}(1)-\mathrm{O}(5 \mathrm{a})$ & $\mathrm{O}(4 \mathrm{~b})-\mathrm{O}(5 \mathrm{a})$ & 2,71 \\
$\mathrm{O}(1)-\mathrm{O}(5 \mathrm{~b})$ & $\mathrm{O}(5 \mathrm{a})-\mathrm{O}(5 \mathrm{~b})$ & 1,67 \\
$\mathrm{O}(6)-\mathrm{O}(4 \mathrm{a})$ & & \\
$\mathrm{O}(6)-\mathrm{O}(4 \mathrm{~b})$ & 0,63 & $\mathrm{Bi}_{2} \mathrm{O}_{2}$ sheets & \\
$\mathrm{O}(6)-\mathrm{O}(5 \mathrm{a})$ & 0,63 & $\mathrm{O}(2)-\mathrm{O}(2)$ & 1,60 \\
$\mathrm{O}(6)-\mathrm{O}(5 \mathrm{~b})$ & 1,73 & $\mathrm{O}(3)-\mathrm{O}(3)$ & 1,60 \\
\hline
\end{tabular}

With a migration energy of $1.6 e V$, the diffusion of oxide ion within the $\mathrm{Bi}_{2} \mathrm{O}_{2}$ layers is difficult. The low energy pathway involves a zigzag type mechanism between adjacent apical $\mathrm{O}(1,6)$ and equatorial $\mathrm{O}(4,5)$ sites, with an alternative sequence of migration energies of 0.45 and $0.63 \mathrm{eV}$. In view of this type of motion, highly anisotropic ionic conductivity was expected with an activation energy of $0.63 \mathrm{eV}$. An activation energy of $0.6 \mathrm{eV}$ was derived above $500^{\circ} \mathrm{C}$ from impedance spectroscopy in good agreement with this calculated value. To explain the increase of the activation energy at temperature below $500^{\circ} \mathrm{C}$, defect association was considered. The formation of a dopant-vacancy cluster would lead to an additional binding energy of $0.25 \mathrm{eV}$, in good agreement with the experimental value of $0.75 \mathrm{eV}$. It was then proposed that the observed slope change in the ionic conductivity could be related to dopant-vacancy association at low temperature. In case of bismuth based compounds, rather low activation energies are usually observed $\left(0.2 \mathrm{eV}\right.$ for $\gamma-\mathrm{Bi}_{4} V_{2} \mathrm{O}_{11}$ and $0.5 \mathrm{eV}$ for $\mathrm{Bi}_{2} \mathrm{WO}_{6}$ derivatives against $1 \mathrm{eV}$ for Brownmillerite). The lone pair of bismuth ions, strongly polarizable, is likely responsible for this, inducing an additional interaction which contributes to push back the ions from one site to another ${ }^{23}$.

\section{OXYGEN TRANSPORT AT THE SCALE OF A UNIT CELL}

The anisotropic conductivity of these materials was confirmed by neutron diffraction which evidenced a high disorder of the oxide ions in the vanadium slabs of BIMEVOX and in the tetrahedral layers of the Brownmillerite. To take into account the whole density of nucleons of the oxide ions, an anharmonic tensor was used to model the thermal motion.

The Probability Density Function (PDF) of the oxygen nucleons around the vanadium atoms in the structure of $\gamma-\mathrm{Bi}_{4} \mathrm{~V}_{2} \mathrm{O}_{11}$ at $700^{\circ} \mathrm{C}$ is given in the following figure. From these PDF, pseudo-potentials were derived. Several possible oxygen pathways were considered and the lowest barrier of energy was obtained for the diffusion of an oxygen from an apical oxygen site towards an equatorial oxygen in the surrounding of the vanadium ion. It led to a value of $0.16 \mathrm{eV}$ in good agreement with the experimental value of $0.2 \mathrm{eV}$ measured by impedance spectroscopy. 


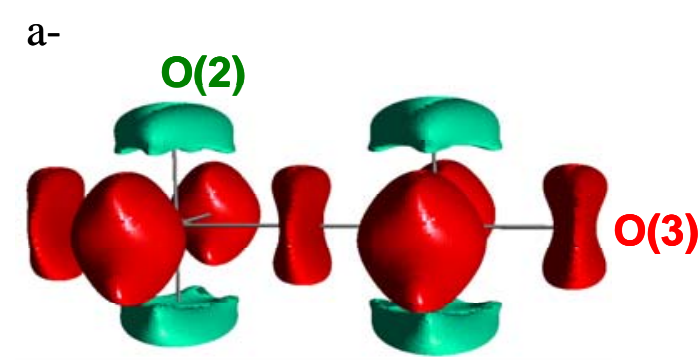

b-
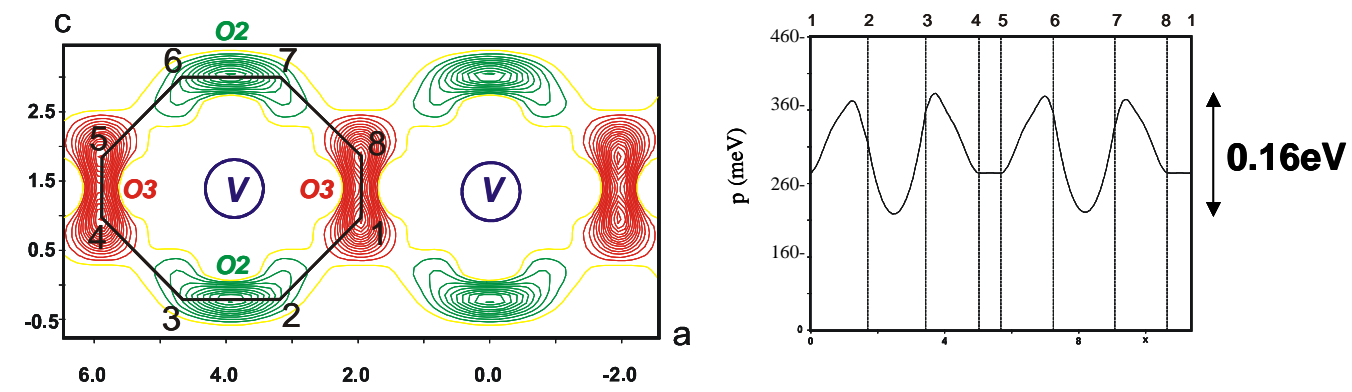

Figure 4. a) Probability Density Function of oxygen nucleons around the vanadium atoms in the structure of $\gamma-\mathrm{Bi}_{4} \mathrm{~V}_{2} \mathrm{O}_{11}$ at $700^{\circ} \mathrm{C}$ b) and derived pseudo-potential

Neutron diffraction was also performed on $\mathrm{Ba}_{2} \mathrm{In}_{2} \mathrm{O}_{5}$ derived compounds. Data were collected at 700 and $950^{\circ} \mathrm{C}$ for composition $\mathrm{Ba}_{2} \mathrm{In}_{2-\mathrm{x}} \mathrm{Mo}_{\mathrm{x}} \mathrm{O}_{5+3 \mathrm{x} / 2}$ with $\mathrm{x}=0.1$. The symmetry of this compound is orthorhombic at room temperature, it becomes tetragonal at $600^{\circ} \mathrm{C}$ and then cubic above $925^{\circ} \mathrm{C}$. The tetragonal form at $700^{\circ} \mathrm{C}$ can be described as a double perovskite corresponding to the intergrowth of octahedral In(1) layers and oxygen deficient In(2) layers. The refinement of the occupancy revealed that molybdenum was preferentially in the In(2) sites. To take into account all the nucleon density of oxygen atoms, an anharmonic model of the thermal motion was also used. The PDF of oxygen nucleons around the indium atoms is given in the next figure. Whereas an important disorder of the oxide ions was observed in the In(2) layers, it was less in the In(1) layers, thus confirming, at this temperature, a two-dimensional mechanism of oxygen diffusion in the oxygen deficient layers. Considering several different oxygen diffusion pathways, the lowest barrier of energy was observed for the jumps from an equatorial site to an adjacent equatorial site in the $\operatorname{In}(2)$ layers with a barrier of $0.4 \mathrm{eV}$ while a barrier of $0.6 \mathrm{eV}$ was calculated for a jump from an equatorial site to an apical site.

At $950^{\circ} \mathrm{C}$, a barrier of energy of $1.1 \mathrm{eV}$ was deduced. The stabilization of the high temperature forms at lower temperature was confirmed by impedance spectroscopy. The value of $1.1 \mathrm{eV}$ derived from the neutron diffraction study at $950^{\circ} \mathrm{C}$ was in good agreement with the experimental value of $1.03 \mathrm{eV}$ observed for the same composition at temperature above $700^{\circ} \mathrm{C}$, in contrast to the value of $0.4 \mathrm{eV}$ deduced at $700^{\circ} \mathrm{C}$. Diffusion at long distance in ceramics is more complex than diffusion at the atomic scale. Other barriers to the diffusion, such as grain boundaries, have to be taken into account. Moreover, one must be careful with the use of these pseudo-potentials since they give only a qualitative information on the possibility of migration and suppose a dynamic disorder of oxide ions. Indeed, one cannot exclude the possibility that the spreading of the nucleon density observed at $700^{\circ} \mathrm{C}$ would be the result of the superimposition of different oxygen surrounding of indium atoms instead of a dynamic disorder. 

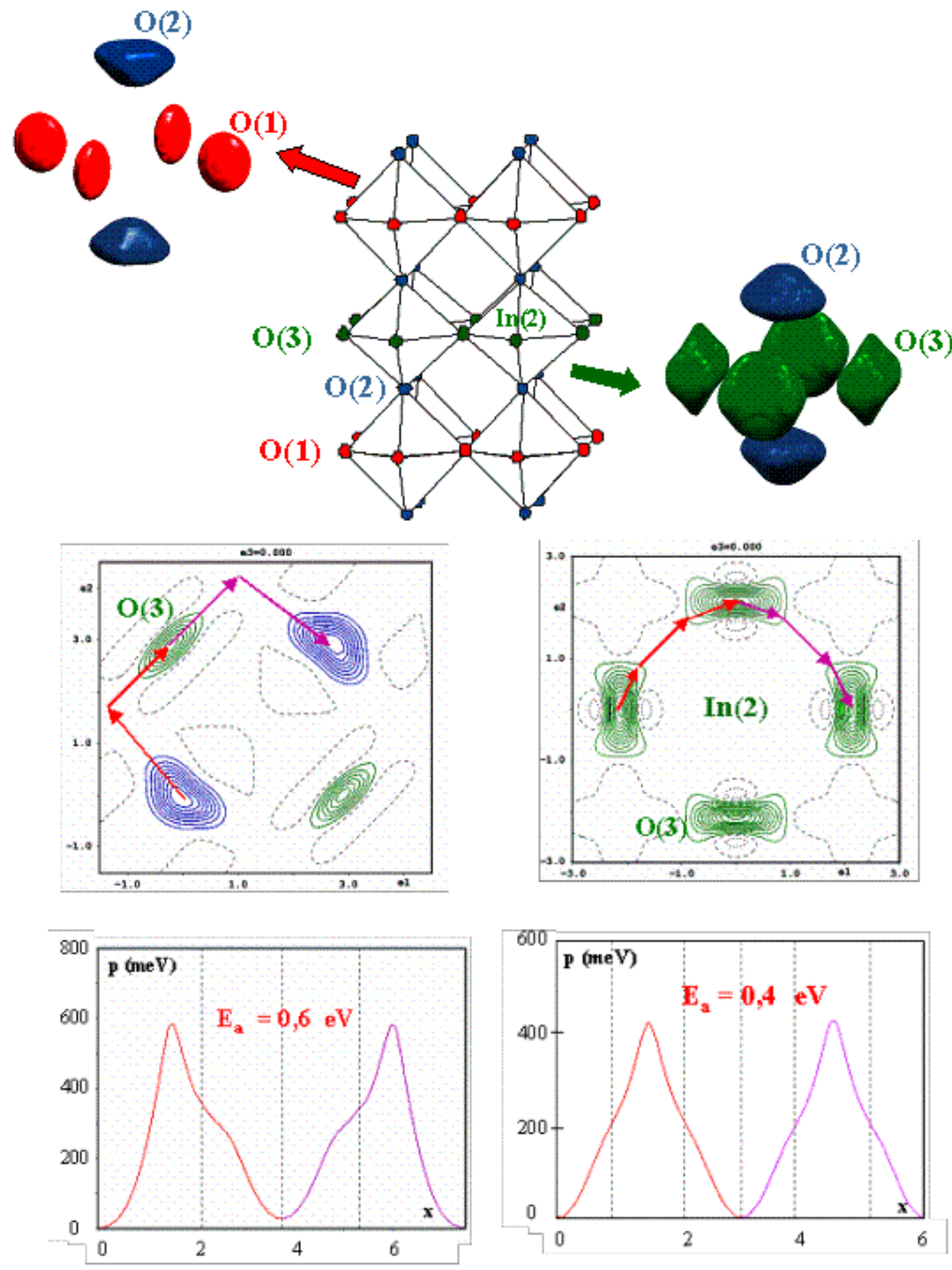

Figure 5. a) Probability Density Function of oxygen nucleons around the indium atoms in the structure of $\mathrm{Ba}_{2} \mathrm{In}_{2-\mathrm{x}} \mathrm{Mo}_{\mathrm{x}} \mathrm{O}_{5+3 \mathrm{x} / 2}$ with $\mathrm{x}=0,1$ at $700^{\circ} \mathrm{C}$ 


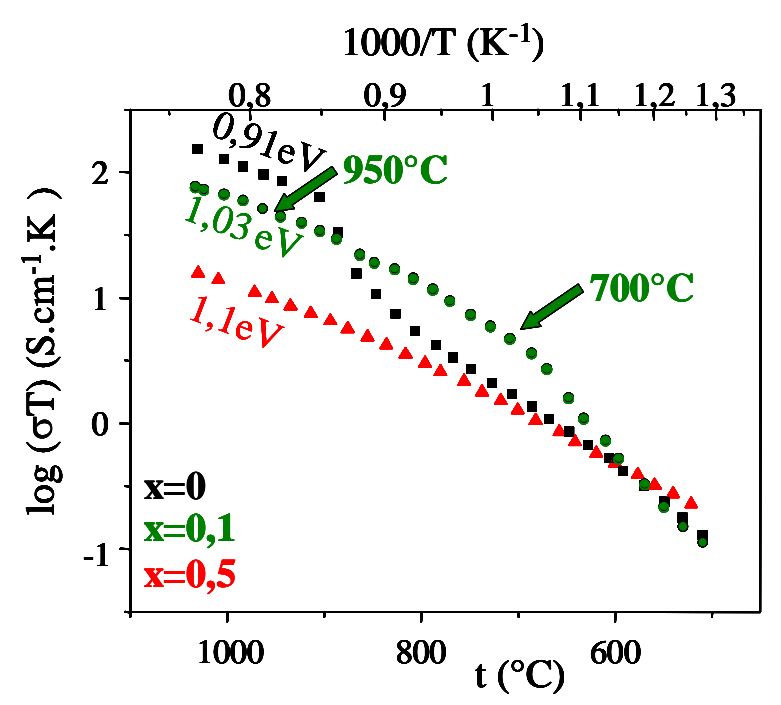

Figure 6. Arrhenius plot of the conductivity of $\mathrm{Ba}_{2} \mathrm{In}_{2-\mathrm{x}} \mathrm{Mo}_{\mathrm{x}} \mathrm{O}_{5+3 \mathrm{x} / 2}$ with $\mathrm{x}=0,0.1$ and 0.5

\section{OXYGEN TRANSPORT AT THE CERAMIC SCALE}

For the applications, dense ceramics are needed. If ceramics with relative density higher than $95 \%$ were easily obtained for the BIMEVOX ${ }^{24,25}$, we did not succeed in optimizing density of the Brownmillerite phases. These compounds absorb and then desorb water between 100 and $400^{\circ} \mathrm{C}$, which complicates their densification. Their conductivities were measured on ceramics with relative density ranging between 60 and $80 \%$.

BIMEVOX materials were tentatively developed as membrane for the electrically driven separation of oxygen from air. Faradic yields close to $100 \%$ with current density up to $2 \mathrm{~A} . \mathrm{cm}^{-2}$ $\left(1 \mathrm{~A} / \mathrm{cm}^{-2}\right.$ is equivalent to $\left.3.5 \mathrm{~cm}^{3} \cdot \mathrm{min}^{-1}\right)$ were obtained with membranes simply made of a dense BIMEVOX ceramic, sandwiched between two gold grids, used as current collector ${ }^{26,27}$. In contrast, low oxygen permeation was observed when membranes were placed between two different atmospheres of oxygen ${ }^{28,29}$.

Permeation is not only a function of the ionic conductivity but also of the electronic conductivity, and a too small electronic conductivity may explain these very low fluxes. However permeation was not improved with a $40 \%$ gold cermet. Another parameter which governs the transport of oxygen in a ceramic is the kinetics of the molecular exchange (dissociation of oxygen molecule into oxide ions and recombination of these ions into molecule) at the surface. To characterize the oxygen transport in these ceramics, ${ }^{18} \mathrm{O} /{ }^{16} \mathrm{O}$ isotope exchanges were performed and the profiles of penetration of ${ }^{18} \mathrm{O}$ were measured by Secondary Ions Mass Spectrometry (SIMS). The high oxygen diffusion in these ceramics was confirmed. However, under dry atmosphere, very weak concentrations of oxygen were measured due to a very slow kinetic of surface exchange. The kinetic was improved under a wet atmosphere ${ }^{30}$. The same experiments were carried out under a current bias, applied between two gold electrodes. Under bias, the oxygen transfer was considerably increased ${ }^{31}$. An in-situ X-ray diffraction study of these membranes under current polarization revealed a slight reduction of the ceramic under bias which was almost reversible when the current was turned off ${ }^{32}$. Under bias, the vanadium, $\mathrm{V}^{\mathrm{V}}$, is slightly reduced into vanadium, $\mathrm{V}^{\mathrm{IV}}$, the electronic conduction is thus enhanced and the oxygen transfer at the surface is then increased. However, without a careful control of the electrical potential, a reduction of bismuth may occur and limit the application of these materials. 


\section{CONCLUSION}

BIMEVOX were evidenced in our lab about 20 years ago. By combining several techniques, we manage to understand their transport of oxygen from the atomic scale to the macroscopic scale. They are fast oxide ion conductors because of their layered structure, their intrinsic oxygen vacancies and this specificity of bismuth ion which possesses a lone pair which contributes to the diffusion process and is likely the cause of the low activation energies observed for bismuth based oxide ion conductors. Unfortunately the main drawback of these materials is their lack of stability under reducing atmosphere which considerably limits their range of application. We applied the same techniques to $\mathrm{Ba}_{2} \mathrm{In}_{2} \mathrm{O}_{5}$ derivatives but were limited by problems of densification. The research of new oxide ion conductors, as stable as stabilized zirconia, with better conductivity, still remains a challenge.

\section{ACKNOWLEDGEMENT}

The authors are very grateful to Professors Jean-Claude Boivin, Gaëtan Mairesse and Guy Nowogrocki who strongly contributed to the study of bismuth-based materials and to the development of BIMEVOX in Lille. The authors must also associate to this work, the group of Professor Saiful Islam of the University of Bath, with whom atomistic calculations were performed, Professor Olivier Isnard and Dr. Emmanuelle Suard at the Institut Laue Langevin for the collection of neutron diffraction data, the group of Professor John Kilner at the Imperial College and the European Community for funding RNV a Marie-Curie Fellowship to carry the characterization of oxygen transport in BIMEVOX by isotope exchange, and all the people who collaborated closely or by far in the characterization of these materials.

\section{REFERENCES}

${ }^{1}$ J.C. Boivin, G. Mairesse, "Recent material developments in fast oxide ion conductors", Chemistry of Materials, 10, 2870-288 (1998).

${ }^{2}$ F. Abraham, J.C. Boivin, G. Mairesse, G. Nowogrocki, "The BIMEVOX series: a new family of high performances oxide ion conductors", Solid State Ionics, 40/41, 934-937 (1990).

${ }^{3}$ F. Abraham, M.F. Debreuille-Gresse, G. Mairesse, G. Nowogrocki, "Phase transitions and ionic conductivity in $\mathrm{Bi}_{4} \mathrm{~V}_{2} \mathrm{O}_{11}$, an oxide with a layered structure", Solid State Ionics, 28-30, 529-532 (1988).

${ }^{4}$ J.B. Goodenough, J.E. Ruiz-Diaz, Y.S. Zhen, "Oxide-ion conduction in $\mathrm{Ba}_{2} \mathrm{In}_{2} \mathrm{O}_{5}$ and $\mathrm{Ba}_{3} \mathrm{In}_{2} \mathrm{MO}_{8}(\mathrm{M}=\mathrm{Ce}, \mathrm{Hf}$, or Zr)", Solid State Ionics, 44, 21-31 (1990).

${ }^{5}$ J.B. Goodenough, A. Manthiram, P. Paranthaman, Y. S. Zhen, "Fast oxide-ion conduction in intergrowth structures", Solid State Ionics, 52, 105-109 (1992).

${ }^{6}$ T. Yao, Y. Uchimoto, M. Kinuhata, T. Inagaki and H. Yoshida., "Crystal structure of Ga-doped $\mathrm{Ba}_{2} \mathrm{In}_{2} \mathrm{O}_{5}$ and its oxide ion conductivity", Solid State Ionics, 132, 189-198 (2000).

${ }^{7}$ M. Yoshinaga, M. Yamaguchi, T. Furuya, S. Wang, T. Hashimoto, "The electrical conductivity and structural phase transitions of cation-substituted $\mathrm{Ba}_{2} \mathrm{In}_{2} \mathrm{O}_{5}$ ", Solid State Ionics, 169, 9-13 (2004).

${ }^{8}$ Y. Uchimoto, Y., M. Kinuhata, T. Yao, "EXAFS study of coordination structures of Gddoped $\mathrm{Ba}_{2} \mathrm{In}_{2} \mathrm{O}_{5}$ ", Japanese Journal of Applied Phys., 38, 111 (1999).

${ }^{9}$ H. Yamamura, Y. Yamada, T. Mori, T. Atake, "Order-disorder transition of oxygen vacancy in the brownmillerite system", Solid State Ionics, 108, 377-381 (1998). 
${ }^{10}$ C.A.J Fisher, B. Derby, R.J. Brook, "Oxygen ion conductivity in brownmilleritestructured oxides, $\mathrm{Ba}_{2} \mathrm{In}_{2-\mathrm{x}} \mathrm{M}_{\mathrm{x}} \mathrm{O}_{5}$, where $\mathrm{M}=\mathrm{Y}$, Yb, Sc, Ga, Br", Ceram. Proc., 56, 25-33 (1996).

${ }^{11}$ K. Kakinuma, H. Yamamura, T. Atake, "Oxide-ion conductivity of the oxygen deficient perovskite solid-solution system, $\left(\mathrm{Ba}_{0.5-\mathrm{x}} \mathrm{Sr}_{\mathrm{x}} \mathrm{La}_{0.5}\right)_{2}\left(\mathrm{In}_{1-\mathrm{y}} \mathrm{M}_{\mathrm{y}}\right) \mathrm{O}_{5.5}(\mathrm{M}=\mathrm{Y}$ or $\mathrm{Ga})$ ", Journal of Thermal Analysis and Calorimetry, 69, 897-904 (2002).

${ }^{12}$ K.R. Kendall, C. Navas, J. K. Thomas, H.C. Loye, "Recent developments in perovskitebased oxide ion conductors", Solid State Ionics, 82, 215-223 (1995).

${ }^{13}$ P. Berastegui, S. Hull, F. J. García-García and S. G. Eriksson, "The crystal structures, microstructure and ionic conductivity of $\mathrm{Ba}_{2} \mathrm{In}_{2} \mathrm{O}_{5}$ and $\mathrm{Ba}\left(\operatorname{In}_{\mathrm{x}} \mathrm{Zr}_{1-\mathrm{x}}\right) \mathrm{O}_{3-\mathrm{x} / 2}$ ", Journal of Solid State Chemistry, 164, 119-130 (2002).

${ }^{14}$ V. Jayaraman, A. Magrez, M. Caldes, O. Joubert, M. Ganne, Y. Piffard, L. Brohan, "Characterization of perovskite systems derived from $\mathrm{Ba}_{2} \mathrm{In}_{2} \mathrm{O}_{5} \square$ Part I: The oxygen-deficient $\mathrm{Ba}_{2} \mathrm{In}_{2(1-\mathrm{x})} \mathrm{Ti}_{2 \mathrm{x}} \mathrm{O}_{5+\mathrm{x}} \square_{1-\mathrm{x}}(0 \leq \mathrm{x} \leq 1)$ compounds", Solid State Ionics, 170, 17-24 (2004).

${ }^{15}$ V. Jayaraman, A. Magrez, M. Caldes, O. Joubert, F. Taulelle, J. Rodriguez-Carvajal, Y. Piffard, L. Brohan, "Characterization of perovskite systems derived from $\mathrm{Ba}_{2} \mathrm{In}_{2} \mathrm{O}_{5} \square$ Part II: The proton compounds $\mathrm{Ba}_{2} \mathrm{In}_{2(1-\mathrm{x})} \mathrm{Ti}_{2 \mathrm{x}} \mathrm{O}_{4+2 \mathrm{x}}(\mathrm{OH})_{\mathrm{y}}[0 \leq \mathrm{x} \leq 1 ; \mathrm{y} \leq 2(1-\mathrm{x})]$ ", Solid State Ionics, 170, 25-32 (2004).

${ }^{16} \mathrm{~T}$. Shimura, T. Yogo, "Electrical properties of the tungsten-doped $\mathrm{Ba}_{2} \mathrm{In}_{2} \mathrm{O}_{5}$ ", Solid State Ionics, 175, 345-348 (2004).

${ }^{17}$ A. Rolle, R.N. Vannier, N.V. Giridharan, F. Abraham, "Structural and electrochemical characterisation of new oxide ion conductors for oxygen generating systems and fuel cells", Solid State Ionics, 176, 2095-2103 (2005).

${ }^{18}$ J.D.Gale, Journal of Chemical Society Faraday Trans., 93, 629 (1997).

${ }^{19}$ M.S. Islam, S. Lazure, R.N. Vannier, G. Nowogrocki, G. Mairesse, "Structural and computational studies of $\mathrm{Bi}_{2} \mathrm{WO}_{6}$ based oxygen ion conductors", J. Mater. Chem., 8, 655-660 (1998).

${ }^{20}$ N. Baux, R.N. Vannier, G. Mairesse, G. Nowogrocki, "Oxide ion conductivity in $\mathrm{Bi}_{2} \mathrm{~W}_{1-\mathrm{x}} \mathrm{ME}_{\mathrm{x}} \mathrm{O}_{6-\mathrm{x} / 2}(\mathrm{ME}=\mathrm{Nb}, \mathrm{Ta})$ ", Solid State Ionics, 91, 243-248 (1996).

${ }^{21}$ C.A.J. Fisher, M.S. Islam, "Defect, protons and conductivity in browmillerite-structured $\mathrm{Ba}_{2} \mathrm{In}_{2} \mathrm{O}_{5}$ ", Solid State Ionics, 118, 355-363 (1999).

${ }^{22}$ K.S. Knight, "The crystal structure of russellite; a re-determination using neutron powder diffraction of synthetic $\mathrm{Bi}_{2} \mathrm{WO}_{6} "$, Mineral. Mag., 56, 399-409 (1992).

${ }^{23}$ C. Pirovano, M.S. Islam, R.N. Vannier, G. Nowogrocki, G. Mairesse, "Modelling the crystal structures of Aurivillius phase", Solid State Ionics, 140, 115-123 (2001).

${ }^{24}$ C. Pirovano, M.C. Steil, E. Capoen, G. Nowogrocki, R.N. Vannier, "Impedance study of the microstructure dependence of the electrical properties of BIMEVOXes", Solid State Ionics, 176, 2079-2083 (2005).

${ }^{25}$ M.C. Steil, F. Ratajczak, E. Capoen, C. Pirovano, R.N. Vannier, G. Mairesse, "Thermal Stability and preparation of dense membrane ceramics of BIMEVOX", Solid State Ionics, 176, 2305-2312 (2005).

${ }^{26}$ E. Capoen, M.C. Steil, G. Nowogrocki, M. Malys, C. Pirovano, A. Löfberg, E. BordesRichard, J.C. Boivin, G. Mairesse, R.N. Vannier, "Oxygen permeation in bismuth-based materials part I: Sintering and oxygen permeation fluxes", Solid State Ionics 177, 483-488 (2006).

${ }^{27}$ A. Löfberg, S. Boujmiai, E. Capoen, M.C. Steil, C. Pirovano, R.N. Vannier, G. Mairesse, E. Bordes-Richard, "Oxygen permeation versus catalytic properties of bismuth-based 
oxide ion conductors used for propene oxidation in a catalytic dense membrane reactor", Catalysis Today, 91-92, 79-83 (2004).

${ }^{28} \mathrm{G}$. Mairesse, "Advances in oxygen pumping concept with BIMEVOX", C.R. Acad. Sci. Paris, t.2, Série IIc, 651-660 (1999)

${ }^{29}$ J.C. Boivin, C. Pirovano, G. Nowogrocki, G. Mairesse, P. Labrune, G. Lagrange, "Electrode-electrolyte BIMEVOX system for moderate temperature oxygen separation", Solid State Ionics, 113-115, 639-651 (1998).

${ }^{30}$ R.N. Vannier, S.J. Skinner, R.J. Chater, J.A. Kilner, G. Mairesse, "Oxygen transfer in BIMEVOX materials", Solid State Ionics, 160, 85-92 (2003).

${ }^{31}$ R.N. Vannier, S.J. Skinner, R.J. Chater, J.A. Kilner, G. Mairesse, "Characterisation of the oxygen transfer in BIMEVOX membranes under applied current conditions", Solid State Ionics, 160, 327-334 (2003). 